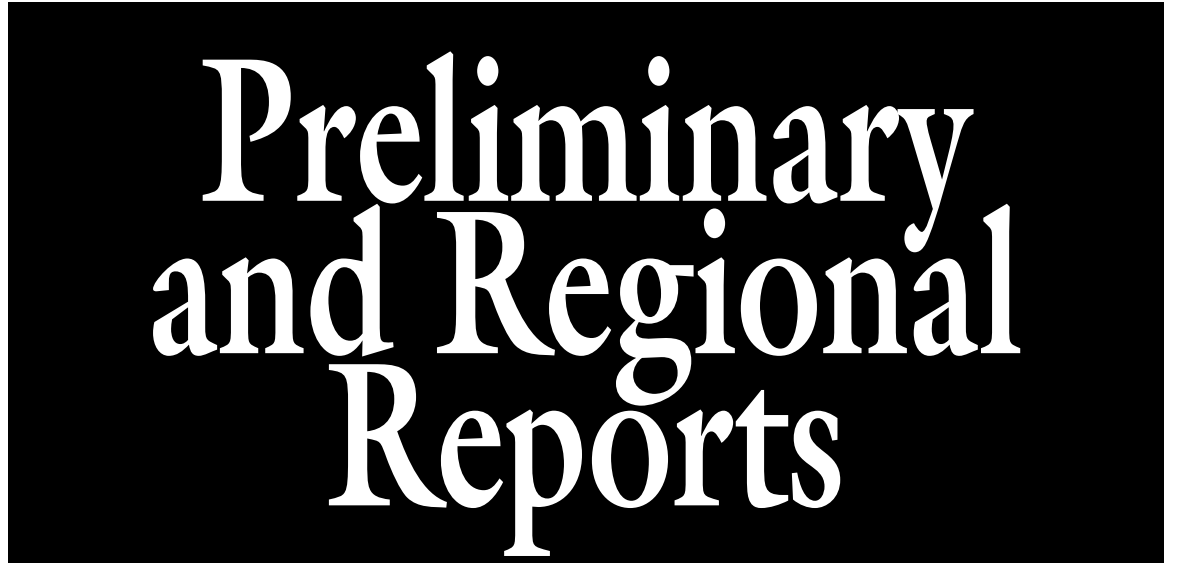

\section{Effect of Colored Shadecloth on the Quality and Yield of Lettuce and Snapdragon}

\author{
Tongyin $\mathrm{Li}^{1}{ }^{1,4}$, Guihong $\mathrm{Bi}^{1}$, Judson LeCompte ${ }^{1}$, \\ T. Casey Barickman ${ }^{2}$, and Bill B. Evans ${ }^{3}$
}

\begin{abstract}
AdDitional INDEX wORDs. photoselective nets, photosynthesis, flavonoids
SuMmARY. Colored shadecloths are used in the production of vegetable, fruit, and ornamental crops to manipulate the light spectrum and to induce specific plant physiological responses. The influence of three colored shadecloths (red, blue, and black) with $50 \%$ shade and a no-shade control on the production of two lettuce (Lactuca sativa) cultivars [Two Star (green-leaf) and New Red Fire (red-leaf)] and snapdragon (Antirrbinum majus) was investigated. Use of shadecloth increased plant growth indices of lettuce and total length of snapdragon flower stems (at the first harvest) compared with no-shade control. Red shadecloth resulted in longer flower stems of snapdragon (at the second harvest) than black and blue shadecloths and no-shade control. However, shadecloth delayed blooming of snapdragon for 1 week compared with no-shade control. Stomatal conductance $\left(g_{s}\right)$ and leaf transpiration rate of both lettuce cultivars and photosynthetic rate and transpiration rate of snapdragon were decreased in response to shadecloth treatments. All shadecloths decreased health beneficial flavonoids (luteolin/quercetin glucuronide and quercetin malonyl concentrations for both lettuce cultivars and cyanidin glucoside in red-leaf lettuce). The two lettuce cultivars varied in their phenolic compounds, with the green-leaf 'Two Star' having higher quercetin glucoside and caftaric acid than red-leaf 'New Red Fire', whereas 'New Red Fire' had higher concentrations of chlorogenic acid, luteolin/quercetin glucuronide, and quercetin malonyl. Shadecloths reduced substrate temperature and photosynthetically active radiation $(P A R)$ to about half of full sunlight compared with no-shade control, which may have contributed to reduced $g_{s}$ and leaf transpiration (for lettuce and snapdragon), decreased phenolic compounds in lettuce, and delayed flowering of snapdragon.
\end{abstract}

$\mathrm{S}$ hadecloth is used in the production of a variety of vegetable, fruit, and ornamental crops, especially in tropical and subtropical regions (Armitage, 1991; Díaz-Pérez, 2013; Halevy et al., 2002; Ilić et al., 2012; Marini and Sowers, 1990; Wolff and Coltman, 1990). Shadecloth provides a microclimate with reduced $P A R$, air temperature, root zone temperature, and changes in relative humidity (Kittas et al., 2012; Stamps, 2009). Shading reduces $P A R$ levels and in some cases air temperature weight decreased with increasing shade level (Díaz-Pérez, 2013).
Plant response to shade varies among species and climatic conditions. For example, Kittas et al. (2012) found shading increased leaf area index, number of fruit per plant, and total yield in tomato (Solanum lycopersicum) during spring and summer in New Anchialos, a coastal area of eastern central Greece. Shade levels of $30 \%$ to $47 \%$ increased yield of lettuce cultivars (Green Mignonette, Salinas, and Amaral 400), WR-55 Days chinese cabbage (Brassica rapa), and Tastie Hybrid head cabbage (Brassica olearacea var. capitata) to different degrees when grown in Hawaii during fall to spring. However, shade $(30 \%, 47 \%, 63 \%$, or $73 \%)$ did not affect crop yield of 'Parris Island Cos' lettuce, 'Waianae Strain' green mustard cabbage (Brassica jun$c e a)$, or green bunching onion ( $A l$ lium fistulosum) (Wolff and Coltman, 1990). Furthermore, Armitage and Son (1992) indicated no difference in yield of blue spirea (Caryopteris incana) when plants were grown under $55 \%$ shade compared with full sunlight in field condition approximated in May at the University of Georgia (Athens). However, shade significantly increased stem length.

Different colored shadecloths, also referred to as photoselective nets, have been used to manipulate the light spectrum to induce specific beneficial plant responses (Basile et al., 2008, 2012; Oren-Shamir et al., 2001; Retamales et al., 2008; Shahak et al., 2004). Altering light quality using colored shadecloth is a sustainable tool in modern fruit production (Bastías and Corelli-Grappadelli, 2012). For example, vegetative growth of 'Hermosa' peach (Prunus persica) was increased by shade nets of different color $(30 \%$ blue, gray, pearl, red, yellow, and 12\% white) (Shahak et al., 2004). By contrast, shadecloth of grey, red, or white color did not affect vegetative growth of 'Berkeley' highbush blueberry ( $V a c$ cinium corymbosum) grown in central Chile (Retamales et al., 2008). Red and pearl colored shadecloths (40\%) significantly increased the total yield of tomato (Ilić et al., 2012; Kittas et al., 2012). Shading also improved tomato fruit quality by reducing cracking and sunscald, and increase marketable fruit percentage (Ilić et al., 2012; Kittas et al., 2012).

Plant photosynthesis is affected by shading because it alters the light 
spectrum, $P A R$, and temperature. Marini and Sowers (1990) reported a nonlinear increase in net photosynthesis of peach 'Redhaven' as photosynthetic photon flux (PPF) level increased from $9 \%, 17 \%, 23 \%, 45 \%$, to $100 \%$, where shading was provided by black polypropylene fabric with different densities. Previous research also indicated increasing shade levels decreased net photosynthesis and $g_{s}$, and increased leaf transpiration of bell pepper (Díaz-Pérez, 2013). In the same study, data suggested shade levels above $47 \%$ may have resulted in excessive transpiration and reduced leaf photosynthesis. Wei et al. (2010) reported reduced yellow vine symptoms of american cranberry (Vaccinium macrocapron) leaves collected from shaded areas. As a result of shade effect, overall photosynthetic activity was improved.

Compared with plant vegetative growth, crop yield, and photosynthetic responses, there is lack of information on how plant chemical compositions, especially phenolic and flavonoid compounds, are affected. Changes in flavonoids in response to colored shade/ netting have been investigated more in fruit crops than in vegetables (Basile et al., 2008; Ilić et al., 2012; Retamales et al., 2008; Shahak et al., 2004). Flavonoids are a group of low-molecular weight polyphenolic compounds, including flavonols, flavones, flavonones, catechins, and isoflavones, and contribute to fruit color, flavor, and bitterness (Robards and Antolovich, 1997; Weisshaar and Jenkins, 1998; WinkeShirley, 2002). They protect plants by absorbing ultraviolet light and visible radiation, and prevent over-excitation

\footnotetext{
This research was supported by Mississippi Department of Agriculture and Commerce - USDA Specialty Crop Block Grant Program and USDA National Institute of Food and Agriculture Hatch project MIS-212050

Mention of a trademark, proprietary product, or vendor does not constitute a guarantee or warranty of the product by Mississippi State University and does not imply its approval to the exclusion of other products or vendors that also may be suitable.

${ }^{1}$ Department of Plant and Soil Sciences, Mississippi State University, Mississippi State, MS 39762

${ }^{2}$ Department of Plant and Soil Sciences, Mississippi State University, North Mississippi Research and Extension Center, Verona, MS 38879

${ }^{3}$ Department of Plant and Soil Sciences, Mississippi State University, Truck Crops Branch Experiment Station, Crystal Springs, MS 39059

${ }^{4}$ Corresponding author. E-mail: tl665@msstate.edu. doi: 10.21273/HORTTECH03809-17
}

of the photosynthetic apparatus (Becker et al., 2013). Their antioxidant activity of scavenging free radicals provides human health benefits of reducing risks of cancer and cardiovascular diseases (Haytowitz, 2003; Jovanovic et al., 1994; Ojong et al., 2008; Rice-Evans et al., 1997).

Use of colored shadecloth has been increasingly adopted in vegetable and cut flower production. Thus, it is of great importance to investigate how colored shadecloths affect plant growth and development, plant physiological activities, and beneficial phytochemicals, such as phenolics and flavonoids. Therefore, the objectives of this study were to investigate the effect of colored shadecloth on: 1) growth and yield of lettuce and snapdragon, 2) physiological activities of lettuce and snapdragon, and 3 ) flavonoid content in lettuce leaf tissue.

\section{Materials and methods}

EXPERIMENT SETUP. This study was conducted in the R.R. Foil Plant Science Research Center at Mississippi State University, Mississippi State, MS (lat. $33.46^{\circ} \mathrm{N}$, long. $88.79^{\circ} \mathrm{W}$ ). Seedlings of lettuce (a green leaf cultivar Two Star and a red leaf cultivar New Red Fire) and snapdragon (Poto$\operatorname{mac}^{\circledR}$ Red; Ball Seed, West Chicago, IL) were transplanted into raised beds $(16 \times 4 \mathrm{ft})$ on 25 Mar. 2015. Pine bark and sand at a ratio of 4:1 (by volume) were used as growing substrate in raised beds. Shadecloths were installed immediately after transplanting. There were four treatments: red shadecloth, blue shadecloth $\left(\right.$ ChromatiNet $^{\circledR}$; Polysack Plastic Industries, Nir Yitzhak, Israel), black shadecloth (Polysack Plastic Industries), and no shadecloth as a control. All of the shadecloths provide $50 \%$ shade according to manufacturer's specifications. Each shadecloth was $28 \mathrm{ft}$ long and $12 \mathrm{ft}$ wide, and installed on a metal frame ( $16 \mathrm{ft}$ long, 4 $\mathrm{ft}$ wide, $5 \mathrm{ft}$ tall) with no shadecloth covering on the north side and about $1 \mathrm{ft}$ off the ground on other three sides of raised bed. There were 12 raised beds with $10 \mathrm{ft}$ between each bed. Twelve snapdragon seedlings were transplanted into half of each raised bed $(8 \times 4 \mathrm{ft})$ in two rows $(1 \mathrm{ft}$ within row, $2 \mathrm{ft}$ between rows). Remaining half of each raised bed was used for lettuce plants, where seven lettuce seedlings of each cultivar were planted $\mathrm{l} \mathrm{ft}$ apart in two separate rows $\mathrm{l} \mathrm{ft}$ apart. Before transplanting, all beds were fertilized by incorporating a controlled-release fertilizer (Osmocote ${ }^{\circledR}$ Plus 15N-3.9P-10K, 5-6 month; Scotts Miracle-Grow Co., Marysville, $\mathrm{OH})$ at medium recommended rate, equivalent to nitrogen at $3 \mathrm{lb} / 1000 \mathrm{ft}^{2}$. All plants were irrigated as needed through drip irrigation.

Surface temperature of growing substrate and leaf surface temperature were measured around noon using a handheld IR thermometer (Traceable; Fisher Scientific, Pittsburgh, PA) on 8 May 2015. Substrate temperature at 4 -inch depth under the shade of lettuce leaves was measured using a probe thermometer at the same time. Plant height and widths were measured on the same day. Plant growth index (PGI) of each plant was calculated as the average of plant height, width 1 (widest points apart), and width 2 (perpendicular to width 1 ).

LETTUCE GROWTH AND HARVEST. Lettuce plants were harvested by cutting at ground level on 10 May 2015, $45 \mathrm{~d}$ after transplanting. Each lettuce plant was weighed for fresh weight. Leaves of one randomly selected

\begin{tabular}{llll}
\hline $\begin{array}{l}\text { Units } \\
\text { To convert U.S. to SI, } \\
\text { multiply by }\end{array}$ & U.S. unit & SI unit & $\begin{array}{l}\text { To convert SI to U.S., } \\
\text { multiply by }\end{array}$ \\
\hline 29,574 & $\mathrm{fl} \mathrm{oz}$ & $\mu \mathrm{L}$ & $3.3814 \times 10^{-5}$ \\
29.5735 & $\mathrm{fl} \mathrm{oz}$ & $\mathrm{mL}$ & 0.0338 \\
0.3048 & $\mathrm{ft}$ & $\mathrm{m}$ & 3.2808 \\
0.0929 & $\mathrm{ft}^{2}$ & $\mathrm{~m}^{2}$ & 10.7639 \\
2.54 & inch $(\mathrm{es})$ & $\mathrm{cm}$ & 0.3937 \\
25.4 & inch(es) & $\mathrm{mm}$ & 0.0394 \\
6.4516 & inch & $\mathrm{cm}^{2}$ & 0.1550 \\
4.8824 & lb/l,000 $\mathrm{ft}^{2}$ & ${\mathrm{~g} \cdot \mathrm{m}^{-2}}^{2}$ & 0.2048 \\
1 & micron $(\mathrm{s})$ & $\mu \mathrm{m}$ & 1 \\
28.3495 & $\mathrm{Oz}$ & $\mathrm{g}$ & 0.0353 \\
0.001 & $\mathrm{ppm}$ & $\mathrm{mg} \cdot \mathrm{g}^{-1}$ & 1,000 \\
$\left({ }^{\circ} \mathrm{F}-32\right) \div 1.8$ & ${ }^{\circ} \mathrm{F}$ & ${ }^{\circ} \mathrm{C}$ & $\left({ }^{\circ} \mathrm{C} \times 1.8\right)+32$
\end{tabular}


lettuce plant from each replication under each treatment were separated and measured for leaf area using a leaf area meter (LI-3100C; LI-COR Biosciences, Lincoln, NE). A different lettuce plant from each replication was randomly selected and ovendried at $60{ }^{\circ} \mathrm{C}$ to a constant weight for its dry weight. A third lettuce plant from each replication was freeze-dried by a freeze dry system (FreeZone ${ }^{\circledR}$ 6; Labconco, KS City, $\mathrm{MO}$ ), where $100 \mathrm{~g}$ of fresh leaf tissue without major vascular tissues were collected. Freeze-dried leaf samples were ground to pass a 40-mesh $(0.42 \mathrm{~mm})$ sieve using a Wiley mill (Digital ED-5; Thomas Scientific, Swedesboro, NJ) and used for analysis of flavonoid compounds.

Analyses OF PHENOLIC compounds. Flavonoid analyses, including flavonol and flavone glycosides (quercetin glucoside, quercetin glucuronide, quercetin malonyl, and luteolin glucuronide), anthocyanin glycosides (cyaniding glucoside), and phenolic acids (caftaric acid and chlorogenic acid), were conducted according to Becker et al. (2013) with modification. These compounds were reported to be the major flavonoid compounds in lettuce leaf tissue (Becker et al., 2013; Llorach et al., 2008). A 0.1 -g subsample was extracted in a $15-\mathrm{mL}$ testtube by adding $2.5 \mathrm{~mL}$ of extraction solvent (60:37:3 by volume) consisting of methanol, deionized water, and formic acid. Samples were vortexed for $1 \mathrm{~min}$ and then centrifuged at $3000 g_{\mathrm{n}}$ for $20 \mathrm{~min}$. After centrifugation, the supernatant was transferred into a new 15-mL testtube and kept on ice. This process was repeated two more times for a total volume of $7.5 \mathrm{~mL}$ of supernatant collected. After the transfers, the tubes were mixed by inversion and samples were filtered through a $0.2-\mu \mathrm{m}$ syringe filter and collected in a $2-\mathrm{mL}$ vial for analysis. Separation parameters and quantification of flavonoid compounds were carried out with authentic standards using highperformance liquid chromatograph (Infinity 1260 series; Agilent Technologies, Willington, DE). Chromatographic separations were achieved using a $150 \times 4.6-\mathrm{mm}$ i.d., $2.6-\mu \mathrm{m}$ analytical scale reverse-phase column (Kinetex F5; Phenomenex, Torrance, CA), which allowed for effective separation of chemically similar flavonoid compounds. The column was equipped with a Kinetex F5 $12.5 \times$ 4.6- $\mathrm{mm}$ i.d. guard cartridge and holder and was maintained at $30^{\circ} \mathrm{C}$ using a thermostat column compartment. All separations were achieved using gradient mobile phase of 1 ) reverse osmosis water adjusted to pH 2.5 with trifluoroacetic acid and 2 ) acetonitrile. The gradient held the following percentages: $15 \%$ to $35 \%$ (20 min), $30 \%$ to $15 \%$ ( $1 \mathrm{~min}$ ), and $15 \%(2 \mathrm{~min})$. The flow rate was $1.0 \mathrm{~mL} \cdot \mathrm{min}^{-1}$, with a run time of $21 \mathrm{~min}$, followed by a 2 -min equilibration before the next injection. Eluted compounds from a $10-\mu \mathrm{L}$ injection loop were detected and data were recorded and integrated using ChemStation software (Agilent Technologies). The peak assignment for an individual phenolic compound was performed by comparing retention times from the multiple wavelength detector using external standards of quercetin glucoside, quercetin glucuronide, quercetin malonyl, luteolin glucuronide, caftaric acid, chlorogenic acid, and cyanidin glucoside (Sigma-Aldrich, St. Louis, MO).

SNAPDRAGON FLOWER STEM HARVEST. For snapdragon, first flower date was recorded for each replication. A flower stem was considered ready for harvest when an inflorescence had a third of its florets blooming. Flower stems of snapdragon were harvested on a weekly basis. Total flower stem length and length of the inflorescence were recorded at each harvest. At the first harvest, the central main stem was harvested from each plant, leaving two basal nodes below each cut. Branching from the basal nodes resulted in a second harvest. The number of flower stems harvested from each plant was recorded at the second harvest. Both first and second harvests were completed over a period of several weeks considering individual plants bloomed at different times.

Photosynthesis and Related measurements. Photosynthetic activities were measured on snapdragon and lettuce using a portable photosynthesis system (LI-6400XT, LICOR Biosciences). A clear chamber was used to measure photosynthesis for lettuce and snapdragon plants on 8 and 13 May 2015, respectively, where ambient light (with or without shade) in each treatment was used as light source. Block temperature inside the leaf chamber was maintained according to ambient temperature at the time of measurement, $32{ }^{\circ} \mathrm{C}$ on 8 May and $29^{\circ} \mathrm{C}$ on 13 May. Two randomly selected plants (snapdragon and lettuce) from each replication were measured for photosynthetic activities. One reading was taken for each selected plant from one of the first three fully expanded leaves. For lettuce plants, photosynthetic readings were taken from an area on the selected leaf not shaded by other leaves. Readings of photosynthetic rate, $\mathscr{g}_{\mathrm{s}}$, leaf transpiration rate, and $P A R$ were recorded between 1100 and $1300 \mathrm{HR}$.

EXPERIMENTAL DESIGN AND ANALYSES. This experiment was a randomized complete block design. Each treatment had three replications (three raised beds), and each replication had 12 (for snapdragon) or 7 (for each lettuce cultivar) subsamples. Green- and red-leaf lettuce were set as subplots. Data from the two crops were analyzed as separate experiments. Significance of any main effect was determined using the analysis of variance (ANOVA). Where indicated by ANOVA, means were separated by Tukey's honest significant difference test at $P<0.05$. All statistical analyses were performed using SAS (version 9.4; SAS Institute, Cary, NC).

\section{Results}

LETTUCE GROWTH AND YIELD. Shadecloth of red, blue, and black resulted in comparable (11.92, 11.93 , and $11.75 \mathrm{~cm}$, respectively), but higher PGI of lettuce compared with no-shade control $(9.83 \mathrm{~cm})[P<$ 0.0001 (Table 1)]. Red shadecloth resulted in lettuce yield of $296.8 \mathrm{~g}$, in terms of fresh lettuce weight, which was $33.8 \%$ higher than no-shade control and comparable to blue and black shades $[P=0.004$ (Table 1$)]$. Red shade resulted in $59.5 \%$ higher leaf area of lettuce than control, but comparable with leaf area found under blue and black shadecloths $[P=0.04$ (Table 1)]. Dry weight of lettuce was unaffected by any shadecloth treatment $(P=0.3)$. Between cultivars, Two star green-leaf lettuce had significantly higher PGIs $(P=0.0001)$, fresh weight $(P=0.001)$, and dry weight $(P=0.001)$ than New Red Fire red-leaf lettuce by $6.7 \%, 21.1 \%$, 
and $47.3 \%$, respectively (Table 2 ). There was no significant interaction between lettuce cultivar and shade treatment in PGI $(P=0.45)$, leaf area $(P=0.65)$, fresh $(P=0.88)$, or dry weight $(P=0.67)$.

LeTtuCe LEAF AND SUBSTRATE TEMPERATURES. Lettuce leaf surface temperatures were similar among all treatments, averaging from 25.8 to $28.0{ }^{\circ} \mathrm{C}$ (Table 1). However, noshade control had higher substrate temperature, both at surface $(P<$ $0.0001)$ and at 4 -inch depth $(P<$ 0.0001 ) under shade of lettuce leaves, than shadecloth treatments. Surface temperature of no-shade control growing substrate averaged $53.9^{\circ} \mathrm{C}$ compared with 35.4 to $39.9^{\circ} \mathrm{C}$ under shadecloths. Among shadecloth treatments, red shade resulted in higher substrate temperature at 4 -inch depth than black shadecloth (Table 1). Leaf surface temperatures $(P=0.89)$ and substrate temperatures at 4 -inch depth $(P=0.26)$ were similar between lettuce cultivars (Table 2 ).

LETTUCE PHOTOSYNTHESIS AND RELATED MEASUREMENTS. When measured on 8 May 2015, photosynthetic rate was comparable among all treatments (Table 3). However, no-shade control resulted in higher $g_{\mathrm{s}}(P<0.0001)$ by $46.6 \%, 36.2 \%$, and $29.3 \%$ than black, blue, and red shades and higher leaf transpiration rate $(P<0.0001)$ in lettuce plants by $36.4 \%, 24.6 \%$, and $19.7 \%$ than black, blue, and red shades, respectively. There was a higher PAR (1868 $\mu \mathrm{mol} \cdot \mathrm{m}^{-2} \cdot \mathrm{s}^{-1}$ on average) with noshade control than any type of shadecloth treatment, 696, 774, and 815 $\mu \mathrm{mol} \cdot \mathrm{m}^{-2} \cdot \mathrm{s}^{-1}$ under blue, red, and black shadecloths, respectively. Photosynthesis and related readings including $\mathscr{g}_{s}$, leaf transpiration rate, and $P A R$ were all similar between lettuce cultivars (data not shown), suggesting these activities were influenced more by shading than by different lettuce cultivars.

Phenolic Compounds in LETTUCE LEAVES. There was no significant interaction between lettuce cultivar and shade treatment in leaf concentration of quercetin glucoside $(P=0.41)$, luteolin/quercetin glucuronide $(P=0.24)$, quercetin malonyl $(P=0.09)$, caftaric acid $(P=0.12)$, or chlorogenic acid $(P=0.48)$. Of all phenolic compounds tested, two lettuce cultivars varied in leaf concentrations of quercetin glucoside $(P<$ $0.0001)$, luteolin/quercetin glucuronide, quercetin malonyl $(P<0.0001)$, caftaric acid $(P=0.0003)$, and chlorogenic acid $(P<0.0001)$ (Table 4$)$. Luteolin glucuronide and quercetin glucuronide coeluted and were quantified as the sum. 'Two Star' green-leaf lettuce had higher concentrations of quercetin glucoside and caftaric acid, 24 times and 2.5 times of those in 'New Red Fire' red-leaf lettuce. Whereas 'New Red Fire' had higher luteolin/quercetin glucuronide, quercetin malonyl, and chlorogenic acid than 'Two Star', higher by $57.6 \%, 103 \%$, and $161 \%$, respectively. Compared with no-shade control, shadecloths decreased luteolin/ quercetin glucuronide $(P<0.0001)$ and quercetin malonyl concentrations $(P=0.0004)$ regardless of lettuce cultivar and decreased cyanidin glucoside $(P=0.005)$ in red-leaf New Red Fire (Table 5). Cyanidin is a type of anthocyanidin found in many red color fruits and vegetables that is not produced in green-leaf lettuce. Therefore, data for cyanidin concentrations were obtained from red-leaf 'New Red Fire' rather than green-leaf 'Two Star'. SNAPDRAGON FLOWER STEM HARVEST. For both harvests, no-shade control produced harvestable flower stems about 1 week earlier (28 Apr. and 24 May for the first and second harvest, respectively) than those grown under shadecloths (Table 6). Shadecloths produced harvestable flower stems from 4 May to 6 May (at first harvest) and from 1 June to 3 June (at second harvest). At the first

Table 1. Plant growth, leaf, and substrate temperatures affected by a black, red, and blue shadecloth or no-shade control across two lettuce cultivars, Two Star and New Red Fire.

\begin{tabular}{|c|c|c|c|c|c|c|c|}
\hline Shade $^{\mathrm{z}}$ & PGI $(\mathrm{cm})^{\mathrm{y}}$ & Fresh wt $(g)^{x}$ & Dry wt (g) & Leaf area $\left(\mathrm{cm}^{2}\right)^{\mathrm{x}}$ & $\begin{array}{l}\text { Leaf surface } \\
\text { temp }\left({ }^{\circ} \mathbf{C}\right)^{\mathrm{x}}\end{array}$ & $\begin{array}{l}\text { Substrate temp of } 4 \text {-inch } \\
(10.2 \mathrm{~cm}) \text { depth }\left({ }^{\circ} \mathrm{C}\right)\end{array}$ & $\begin{array}{c}\text { Substrate surface } \\
\text { temp }\left({ }^{\circ} \mathrm{C}\right)\end{array}$ \\
\hline Black & $11.75 \mathrm{a}^{\mathrm{w}}$ & $253.7 \mathrm{ab}$ & 16.8 & $4,812 \mathrm{ab}$ & $26.0 \mathrm{a}$ & $21.4 \mathrm{c}$ & $35.4 \mathrm{~b}$ \\
\hline Red & $11.92 \mathrm{a}$ & 296.8 a & 19.9 & $6,006 \mathrm{a}$ & $26.1 \mathrm{a}$ & $22.2 \mathrm{~b}$ & $39.9 \mathrm{~b}$ \\
\hline No-shade & $9.83 \mathrm{~b}$ & $221.8 \mathrm{~b}$ & 19.6 & $3,766 \mathrm{~b}$ & $28.0 \mathrm{a}$ & $23.5 \mathrm{a}$ & $53.9 \mathrm{a}$ \\
\hline$P$ value & $<0.0001$ & 0.004 & 0.3 & 0.04 & 0.12 & $<0.0001$ & $<0.0001$ \\
\hline
\end{tabular}

PGI = plant growth index.

${ }^{\mathrm{z}}$ Lettuce plants were grown in raised beds under a black, blue, or red colored shadecloth with $50 \%$ shade, or in beds with no shadecloth as control.

${ }^{y}$ Plant growth index $=[$ plant height + plant width 1 (greatest width) + plant width 2 (perpendicular to width 1$\left.)\right] \div 3 ; 1 \mathrm{~cm}=0.3937$ inch .

${ }^{\mathrm{x}} \mathrm{l} \mathrm{g}=0.0353 \mathrm{oz}, \mathrm{l} \mathrm{cm}{ }^{2}=0.1550$ inch $^{2}, 1.8 \times{ }^{\circ} \mathrm{C}+32={ }^{\circ} \mathrm{F}$.

wDifferent lowercase letters within a column suggests significant difference indicated by Tukey's honest significant difference test at $P<0.05$.

Table 2. Plant growth, leaf, and substrate temperatures affected by lettuce cultivars across four shadecloth treatments, including a black, red, and blue shade, and a no-shade control.

\begin{tabular}{lcccccc}
\hline Cultivar & PGI $(\mathbf{c m})^{\mathbf{z}}$ & Fresh wt $(\mathbf{g})^{\mathbf{y}}$ & Dry wt $(\mathbf{g})$ & Leaf area $\left(\mathbf{c m}^{2}\right)^{\mathbf{y}}$ & $\begin{array}{c}\text { Leaf surface } \\
\text { temp }\left({ }^{\circ} \mathbf{C}\right)^{\mathbf{y}}\end{array}$ & $\begin{array}{c}\text { Substrate temp at 4-inch } \\
(\mathbf{1 0 . 2} \mathbf{~ c m}) \text { depth }\left({ }^{\circ} \mathbf{C}\right)\end{array}$ \\
\hline Two Star & 11.73 & 278.3 & 21.5 & 4,307 & 26.5 & 22.1 \\
New Red Fire & 10.99 & 229.8 & 14.6 & 5,041 & 26.4 & 22.3 \\
$P$ value $^{\mathrm{x}}$ & 0.0001 & 0.001 & 0.001 & 0.49 & 0.89 & 0.26 \\
\hline
\end{tabular}

PGI = plant growth index.

${ }^{z}$ Plant growth index $=$ [plant height + plant width 1 (greatest width $)+$ plant width 2 (perpendicular to width 1$\left.)\right] \div 3 ; 1 \mathrm{~cm}=0.3937$ inch .

${ }^{\mathrm{y}} \mathrm{l} \mathrm{g}=0.0353 \mathrm{oz}, 1 \mathrm{~cm}^{2}=0.1550 \mathrm{inch}^{2}, 1.8 \times{ }^{\circ} \mathrm{C}+32={ }^{\circ} \mathrm{F}$.

${ }^{\mathrm{x}} \mathrm{A}$ probability value lower than 0.05 suggests significant difference indicated by Tukey's honest significant difference test. 


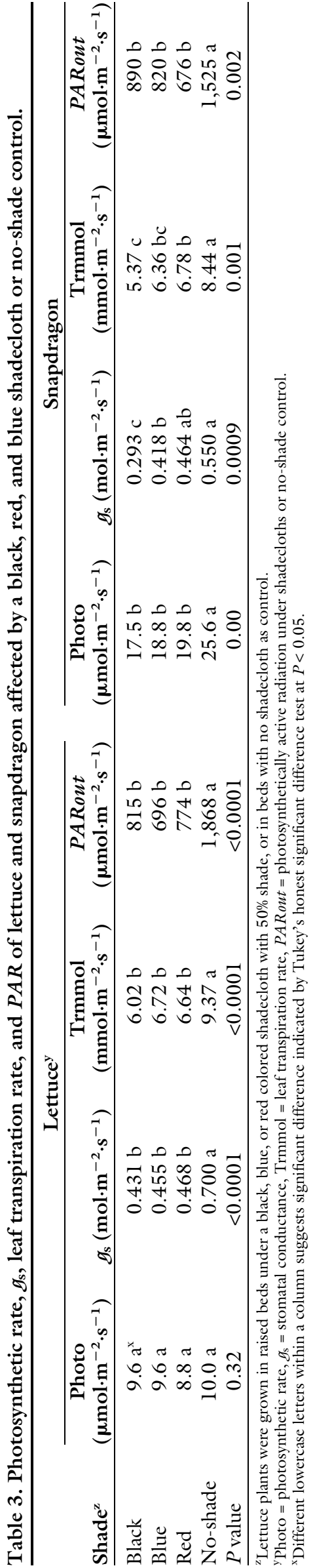

harvest, all shadecloths resulted in longer flower stems than no-shade control by $\approx 10 \mathrm{~cm}(P<0.0001)$, with lengths of inflorescence being similar among all treatments $(P=$ 0.88 ) (Table 6). At the second harvest, red shadecloth produced flower stems $7 \mathrm{~cm}$ longer than flower stems under blue and black shadecloths or no-shade control $(P<0.0001)$. Plants under red shadecloth and no-shade control produced inflorescences $1.6 \mathrm{~cm}$ longer than blue and black shadecloths $(P=0.0002)$. On average, flower stems and inflorescences at the first harvest were 17.95 and $6.73 \mathrm{~cm}$ longer, respectively, than those at the second harvest. Because flower stems at the first harvest were from main stems of each plant, the number of flower stems harvested was equal among treatments. At the second harvest, no-shade control and red shadecloth produced 55 and 50 flower stems, respectively, with blue and black shadecloths producing 33 and 42 flower stems, respectively. However, differences were not statistically significant $(P=0.09)$ because of large variations in flower stem number between replications (Table 6).

SNAPDRAGON PHOTOSYNTHESIS AND RELATED MEASUREMENTS. When measured on 13 May 2015, no-shade control resulted in higher photosynthetic rate $(P=0.005)$, leaf transpiration rate $(P=0.001)$, and PAR $(P=$ 0.002 ) than all shadecloths and higher $g_{\mathrm{s}}$ than blue and black shadecloths (Table 3). There was no difference in photosynthetic rate or PAR among shadecloths. Black shadecloth resulted in $g_{\mathrm{s}}$ of $0.293 \mathrm{~mol} \cdot \mathrm{m}^{-2} \cdot \mathrm{s}^{-1}, 36.8 \%$ lower than red $\left(0.464 \mathrm{~mol} \cdot \mathrm{m}^{-2} \cdot \mathrm{s}^{-1}\right)$, and $29.9 \%$ lower than blue $\left(0.418 \mathrm{~mol} \cdot \mathrm{m}^{2} \cdot \mathrm{s}^{-1}\right)$ shadecloths $(P=0.0009)$. Black shade resulted in leaf transpiration rate of $5.37 \mathrm{mmol} \cdot \mathrm{m}^{-2} \cdot \mathrm{s}^{-1}, 20.8 \%$ lower than red shadecloth of $6.78 \mathrm{mmol} \cdot \mathrm{m}^{-2} \cdot \mathrm{s}^{-1}$, and $36.4 \%$ lower than no-shade control of $8.44 \mathrm{mmol} \cdot \mathrm{m}^{-2} \cdot \mathrm{s}^{-1}(P=0.001)$.

\section{Discussion}

The red shadecloth reduces blue, green, and yellow light in the light spectrum transmitted to plants and increases red and far-red light (Stamps, 2009), which was believed to induce early flowering without decreasing flower quality in orchids (Phalaenopsis cultivars and hybrids) (Leite et al., 2008). Blue shadecloth increased blue light in the light spectrum, introducing an effect of reduced foliage volume and delayed flowering (Basile et al., 2008; Kawabata et al., 2006). For example, red netting $(30 \%)$ induced earlier flowering of nine orchids compared with blue netting (Leite et al., 2008). Black shadecloth generally decreases radiation level for crops growing beneath it and increases vegetative growth of crops such as highbush blueberry (Díaz-Pérez, 2013; Kawabata et al., 2006; Retamales et al., 2008; Stamps, 2008). The main differences in the microenvironment between no-shade control and shadecloths in this study were 1 ) reduced $P A R$ to about half of full sunlight; 2 ) reduced substrate temperature at surface and 4-inch depth; and 3) altered light spectrum under each shadecloth as described by manufactures (spectrum was not measured in this study). With lettuce and snapdragon planted in double rows in each raised bed, each row was exposed to certain degree of edge effect. However, there was no significant effect from block (replication) in any tested variable, suggesting that all plants were subject to similar edge effects and that these edge effects did not affect separation of treatment effects.

Shadecloth of different colors has varied effects on vegetative and reproductive growth on different species (Stamps, 2009). In this study, black, blue, and red shadecloths demonstrated similar effects in increasing PGI of lettuce and total flower stem length of snapdragon, reducing $g_{s}$ and leaf transpiration of lettuce and snapdragon, reducing quercetin malonyl and cyaniding glucoside in lettuce leaves, and reducing substrate surface temperature and $P A R$. These similar effects were likely attributed to the microclimate under shadecloths with reduced $P A R$ and substrate temperatures rather than altered light quality. However, red shadecloth demonstrated some enhancing effects as increased lettuce fresh weight compared with noshade control and increased length of snapdragon flower stem and inflorescence (at second harvest) compared with blue and black shadecloths. These effects of red shadecloth were consistent with reported studies on promoting leaf expansion and stimulating vegetative growth of various crops such as kiwifruit (Actinidia deliciosa) (Basile 
Table 4. Phenolic compounds in lettuce leaves of two cultivars across four shadecloth treatments, including a black, red, and blue shade, and a no-shade control.

\begin{tabular}{|c|c|c|c|c|c|}
\hline Cultivar & $\begin{array}{c}\text { Quercetin } \\
\text { glucoside }\left(\mathbf{m g} \cdot \mathrm{g}^{-1}\right)^{\mathrm{z}}\end{array}$ & $\begin{array}{l}\text { Luteolin/quercetin } \\
\text { glucuronide }\left(\mathrm{mg} \cdot \mathrm{g}^{-1}\right)^{\mathrm{z}}\end{array}$ & $\begin{array}{c}\text { Quercetin } \\
\text { malonyl }\left(\mathrm{mg} \cdot \mathrm{g}^{-1}\right)\end{array}$ & $\begin{array}{c}\text { Caftaric } \\
\text { acid }\left(\mathbf{m g} \cdot \mathrm{g}^{-1}\right)\end{array}$ & $\begin{array}{l}\text { Chlorogenic } \\
\text { acid }\left(\mathrm{mg} \cdot \mathrm{g}^{-1}\right)\end{array}$ \\
\hline Two Star & 52.15 & 10.94 & 15.3 & 2.10 & 10.41 \\
\hline New Red Fire & 2.16 & 17.24 & 31.0 & 0.85 & 27.15 \\
\hline$P$ value $^{\mathrm{y}}$ & $<0.0001$ & $<0.0001$ & $<0.0001$ & 0.0003 & $<0.0001$ \\
\hline
\end{tabular}

${ }^{\mathrm{z}} 1 \mathrm{mg} \cdot \mathrm{g}^{-1}=1,000 \mathrm{ppm}$.

${ }^{\mathrm{y}} \mathrm{A}$ probability value lower than 0.05 suggests significant difference indicated by Tukey's honest significant difference test.

Table 5. Concentrations of phenolic compounds in lettuce leaves affected by different shadecloth treatments, including a black, red, and blue shade, and a no-shade control.

\begin{tabular}{|c|c|c|c|}
\hline Shade $^{\mathrm{z}}$ & Luteolin/quercetin glucoronide $\left(\mathrm{mg} \cdot \mathrm{g}^{-1}\right)^{\mathrm{y}}$ & Quercetin malonyl $\left(\mathrm{mg} \cdot \mathrm{g}^{-1}\right)$ & Cyanidin glucoside $\left(\mathrm{mg} \cdot \mathrm{g}^{-1}\right)^{\mathrm{x}}$ \\
\hline Black & $14.25 \mathrm{~b}^{\mathrm{w}}$ & $21.55 \mathrm{~b}$ & $6.17 \mathrm{~b}$ \\
\hline Blue & $12.40 \mathrm{c}$ & $20.48 \mathrm{~b}$ & $6.82 \mathrm{~b}$ \\
\hline No-shade & $17.24 \mathrm{a}$ & $30.02 \mathrm{a}$ & $11.50 \mathrm{a}$ \\
\hline$P$ value & $<0.0001$ & 0.0004 & 0.005 \\
\hline
\end{tabular}

${ }^{\mathrm{z}}$ Lettuce plants were grown in raised beds under a black, blue, or red colored shadecloth with $50 \%$ shade, or in beds with no shadecloth as control.

${ }^{\mathrm{y}} \mathrm{l} \mathrm{mg} \cdot \mathrm{g}^{-1}=1,000 \mathrm{ppm}$.

${ }^{\mathrm{x}}$ Cyanidin is a type of anthocyanidin found in many red color fruits and vegetables that is not produced in the green-leaf lettuce. Therefore, data for cyanidin concentrations was merely obtained from 'New Red Fire' red-leaf lettuce rather than green-leaf 'Two Star'. All other data were average of both cultivars.

${ }^{w}$ Different lowercase letters within a column suggests significant difference indicated by Tukey's honest significant difference test at $P<0.05$

et al., 2008; Shahak et al., 2004; Stamps, 2008). In addition, red shadecloth also resulted in higher soil temperature at 4-inch depth, and higher $g_{s}$ and transpiration rate of snapdragon than black shadecloth.

Previous research indicated black shade increased internode, leaf and shoot lengths, and leaf width of highbush blueberry 'Berkeley' grown in central Chile compared with no-net control, whereas shades of gray, red, or white color did not affect plant vegetative growth (Retamales et al., 2008). In this study, black shadecloth resulted in higher luteolin/quercetin glucuronide concentration in lettuce leaves, but lower $\mathscr{y}_{\mathrm{s}}$ of snapdragon than blue and red shadecloths. This suggests changed light quality under different colors of shadecloth may have varying effects on different physiological activities.

Besides influences on vegetative growth, there are also reports of colored shadecloths having both positive and negative effects on reproductive growth, such as flowering, fruit setting, and final yield on ornamental, vegetable, and fruit crops (Basile et al., 2008; Ilić et al., 2012; Retamales et al., 2008; Shahak et al., 2004). Leite et al. (2008) reported $30 \%$ red shade induced earlier flowering of orchid compared with black and blue shades. However, flowering of snapdragon was consistently delayed under all shadecloth treatments by $\approx \mathrm{l}$ week in the present study, possibly limited by reduced $P A R$ and substrate temperatures. Reduced $P A R$ and substrate temperatures under shadecloth possibly resulted in lower $g_{s}$ and leaf transpiration for both lettuce and snapdragon and lower photosynthetic rate for snapdragon compared with noshade control. Similar results occurred on other crops, where photosynthesis of peach 'Redhaven' increased nonlinearly with increasing $P P F$ level (Marini and Sowers, 1990).

Shade is often used in subtropical and tropical area to reduce heat stress (Elad et al., 2007; Retamales et al., 2008). With a crop sensitive to heat stress (e.g., bell pepper), increased temperatures in late spring and early summer can induce flower abortion and reduce bell pepper yield (Deli and Tiessen, 1969; Olle and Bender, 2009). Although net photosynthesis and $g_{s}$ were decreased with increasing shade level on bell pepper, total plant leaf area and individual leaf weight were increased (Díaz-Pérez, 2013). During the experiment duration from 24 Mar. (transplanting of lettuce and snapdragon plants) to 26 June 2015 (last harvest day of snapdragon flowers), local average, maximum, and minimum daily temperature ranged from 40 to $84^{\circ} \mathrm{F}, 43$ to $94^{\circ} \mathrm{F}$, and 34 to $78{ }^{\circ} \mathrm{F}$, respectively (U.S. Department of Agriculture, 2017). In this study, reduced $P A R$ as a result of shading may also have contributed to lower photosynthesis and related activities than no-shade control, but did not decreased lettuce fresh yield or show visible negative effects on snapdragon quality in terms of flower stem length.

Synthesis of phenolic compounds was reported to be partially regulated by environmental light conditions. Colored nets decreased anthocyanins and quercetin 3 -glucoside in apple (Malus domestica) peels by 2 to 6-fold on average, but did not affect chlorogenic acid content of apple fruit compared with full sunlight conditions. Nets of different colors had different effects on flavonoids and chlorogenic acid synthesis (Bastías et al., 2012). In another study, photoselective hail nets of blue, gray, red, and white color all decreased polyphenol concentrations and antioxidant activity of kiwifruit grown in southern Italy (Basile et al., 2012). In the present study, shadecloth effect was generally consistent in reducing luteolin/ quercetin glucuronide, quercetin malonyl, and cyaniding glucoside, except that the black shadecloth resulted in higher luteolin/quercetin glucuronide than blue and red shadecloths. Because phenolic compounds act to protects plants from ultravioletB damage (Ojong et al., 2008; Winke-Shirley, 2002) and ultraviolet radiation has been found to be one of the most effective stimuli in pigment formation (Jakopic et al., 
2007; Reay and Lancaster, 2001), it is reasonable that their concentrations were decreased under shadecloth compared with no-shade control with full sunlight. Health benefits of lettuce in lower risk of cardiovascular diseases in human were largely attributed to proficient supply of antioxidant compounds, mainly vitamin $\mathrm{C}$, polyphenols, and fiber content (Nicolle et al., 2004; Serafini et al., 2002). The tested flavonoids compounds in the present study are among the major components in lettuce polyphenol profile (Becker et al., 2013) and reflect how health benefits are affected when lettuce are grown under shade. Health benefits of many of these substances were published. For example, quercetin-3-O(6"-O-malonyl)-glucoside was observed to have antioxidative and antiatherogenic effects (Enkhmaa et al., 2005). Cyanidin-3-O-(6"-O-malonyl)-glucoside inhibited lipid peroxidation and cyclooxygenase enzymes in vitro (Mulabagal et al., 2010).

In summary, use of $50 \%$ shadecloths (red, blue, and black) increased lettuce PGI and fresh weight, and total flower stem length of snapdragon. Black, red, and blue shadecloths generally had similar effects. However, red shade showed superior effect by resulting in longer flower stems of snapdragon and inflorescence at the second harvest compared with blue and black shadecloths. All three shadecloths reduced $g_{s}$, leaf transpiration rate, and PAR for lettuce and snapdragon, delayed snapdragon flowering for about 1 week similarly compared with no-shade control. Such effects may have resulted from the lowered substrate temperatures and reduced $P A R$ under shadecloths. Compared with increased fresh weight, shadecloths decreased concentrations of health beneficial antioxidant compounds (flavonoids) in lettuce leaves.

\section{Literature cited}

Armitage, A.M. 1991. Shade affects yield and stem length of field-grown cut-flower species. HortScience 26:1174-1176.

Armitage, A.M. and K. Son. 1992. Shade and photoperiod influence Caryopteris incana used as cut flower. HortScience 27:1275-1276.

Basile, B., M. Giaccone, C. Cirillo, A. Ritieni, G. Graziani, Y. Shahak, and M. Forlani. 2012. Photo-selective hail nets affect fruit size and quality in Hayward kiwifruit. Sci. Hort. 141:91-97.

Basile, B., R. Romano, M. Giaccone, E. Barlotti, V. Colonna, C. Cirillo, Y. Shahak, and M. Forlani. 2008. Use of photoselective nets for hail protection of kiwifruit vines in southern Italy. Acta Hort. 770:185-192.

Bastías, R.M. and L. Corelli-Grappadelli. 2012. Light quality management in fruit orchards: Physiological and technological aspects. Chil. J. Agr. Res. 72:574-581.

Bastías, R.M., K. Ruíz, L. Manfrini, E. Pierpaoli, M. Zibordi, B. Morandi, P. Losciale, P. Torrigiani, and L. CorelliGrappadelli. 2012. Effects of photoselective nets on phenolic composition in apple fruits. Acta Hort. 939:77-83.

Becker, C., H. Kläring, L.W. Kroh, and A. Krumbein. 2013. Temporary reduction of radiation does not permanently reduce flavonoid glycosides and phenolic acids in red lettuce. Plant Physiol. Biochem. 72:154-160.

Deli, J. and H. Tiessen. 1969. Interaction of temperature and light intensity on flowering of Capsicum frutescens var. grossum cv. California Wonder. J. Amer. Soc. Hort. Sci. 40:493-497.

Díaz-Pérez, J.C. 2013. Bell pepper (Capsicum annum L.) crop as affected by shade level: Microenvironment, plant growth, leaf gas exchange, and leaf mineral nutrient concentration. HortScience 48:175-182.

Elad, Y., Y. Messika, M. Brand, D.R. David, and A. Sztejnberg. 2007. Effect of colored shade nets on pepper powdery mildew (Leveillula taurica). Phytoparasitica 35:285-299.

Enkhmaa, E., K. Shiwaku, T. Katsube, K. Kitajima, E. Anuurad, M. Yamasaki, and Y. Yamane. 2005. Mulberry (Morus alba L.) leaves and their major flavonol quercetin 3-(6-malonylglucoside) attenuate atherosclerotic lesion development in LDL receptordeficient mice. J. Nutr. 135:729-734.

Halevy, A.H., E. Shlomo, and O. Ziv. 2002. Improving cut flower production of balloon flower. HortScience 37:759-761.

Haytowitz, D.B., A.L. Eldridge, S. Bhagwat, S.E. Gebhardt, J.M. Holden, G.R. Beecher, J. Peterson, and J. Dwyer. 2003. Flavonoid content of vegetables. 1 Aug. 2017. <http://www.ars.usda. gov/SP2UserFiles/Place/80400525/ Articles/AICR06_flav.pdf>.

Ilić, Z.S., L. Milenković, L. Stanojević, D. Cvetković, and E. Fallic. 2012. Effects of the modification of light intensity by color shade nets on yield and quality of tomato fruits. Sci. Hort. 193:90-95. 
Jakopic, J., V. Robert, and F. Stampar. 2007. The effect of reflective foil and hail nets on the lighting, color and anthocyanins of 'Fuji' apple. Sci. Hort. 115:40-46.

Jovanovic, S.V., S. Steenken, M. Tosic, B. Marjanovic, and M.G. Simic. 1994. Flavonoids as antioxidants. J. Amer. Chem. Soc. 116:4846-4851.

Kawabata, A.F., J.S. Lichty, K.D. Kobayashi, and W.S. Sakai. 2006. Effects of photoselective shade cloths on potted Dracaena deremensis 'Janet Craig' and Dracaena marginata 'Colorama'. J. Hawaiian Pacific Agr. 14:49-54.

Kittas, C., N. Katsoulas, N. Rigakis, T. Bartzanas, and E. Kitta. 2012. Effects on microclimate, crop production and quality of a tomato crop grown under shade nets. J. Hort. Sci. Biotechnol. 87:7-12.

Leite, C.A., R.M. Ito, G.T.S. Lee, R. Ganelevin, and M.A. Fagnani. 2008. Light spectrum management using colored nets to control the growth and blooming of Phalaenopsis. Acta Hort. 770:193-197.

Llorach, R., A. Martínes-Sánchez, F.A. Tomás-Barberán, M.I. Gill, and F. Ferreres. 2008. Characterisation of polyphenols and antioxidant properties of five lettuce varieties and escarole. Food Chem. 108:1028-1038.

Marini, R.P. and D.L. Sowers. 1990. Net photosynthesis, specific leaf weight, and flowering of peach as influenced by shade. HortScience 25:331-334.

Mulabagal, V., M. Ngouajio, A. Nair, Y. Zhang, A.L. Gottumukkala, and M.G. Nair. 2010. Vitro evaluation of red and green lettuce (Lactuca sativa) for functional food properties. Food Chem. 118:300-306.

Nicolle, C., A. Carnat, D. Fraisse, J.L. Lamaison, E. Rock, H. Michel, P. Amouroux, and C. Remesy. 2004. Characterisation and variation of antioxidant micronutrients in lettuce (Lactuca sativa folium). J. Sci. Food Agr. 84:2061-2069.
Ojong, P.B., V. Njiti, Z. Guo, M. Gao, S Besong, and S.L. Barnes. 2008. Variation of flavonoid content among sweet potato accessions. J. Amer. Soc. Hort. Sci. 133:819-824.

Olle, M. and I. Bender. 2009. Causes and control of calcium deficiency disorders in vegetables: A review. J. Hort. Sci. Biotechnol. 84:577-584.

Oren-Shamir, M., E.E. Gussakovsky, E. Shpiegel, A. Nissim-Levi, K. Ratner, R. Ovadia, Y.E. Giller, and Y. Shakak. 2001. Coloured shade nets can improve the yield and quality of green decorative branches of Pittosporum variegatum. J. Hort. Sci. Biotechnol. 76:353-361.

Reay, P.F. and J.E. Lancaster. 2001. Accumulation of anthocyanins and quercetin glycosides in 'Gala' and 'Royal Gala' apple fruit skin with ame-B-visible irradiation: Modifying effects of fruit maturity, fruit side, and temperature. Sci. Hort. 90:57-68.

Retamales, J.B., J.M. Montecino, G.A. Lobos, and L.A. Rojas. 2008. Colored shading nets increase yield and profitability of highbush blueberries. Acta Hort. 770:193-197.

Rice-Evans, C.A., N.J. Miller, and G. Paganga. 1997. Antioxidant properties of phenolic compounds. Trends Plant Sci. 2:152-159.

Robards, K. and M. Antolovich. 1997. Analytical chemistry of fruit bioflavonoids: A review. Analyst 122:11R-34R.

Serafini, M., R. Bugianesi, M. Salucci, E. Azzini, A. Raguzzini, and G. Maiani. 2002. Effect of acute ingestion of fresh and stored lettuce (Lactuca sativa) on plasma total antioxidant capacity and antioxidant levels in human subjects. Brit. J. Nutr. 88:615-623.
Shahak, Y., E.E. Gussakovsky, Y. Cohen, S. Lurie, R. Stern, S. Kfir, A. Naor, I. Atzmon, I. Doron, and Y. GreenblatAvron. 2004. ColorNets: A new approach for light manipulation in fruit trees. Acta Hort. 636:609-616.

Smith, I.E., M.J. Savage, and P. Mills. 1984. Shading effects on greenhouse tomatoes and cucumbers. Acta Hort. 148:229-237.

Stamps, R.H. 2008. Differential effects of colored shade nets on three cut foliage crops. Acta Hort. 770:169-176.

Stamps, R.H. 2009. Use of colored shade netting in horticulture. HortScience 44:239-241

U.S. Department of Agriculture. 2017. Report generator 2.0. 7 Aug. 2017. <https:// wcc.sc.egov.usda.gov/reportGenerator/>.

Wei, Z., P. Jeranyama, F. Zhang, C. DeMoranville, and H.J.M. Hou. 2010. Probing the mechanisms of the yellow vine syndrome development in the american cranberry: Shade effect. HortScience 45:1345-1348

Weisshaar, B. and G.I. Jenkins. 1998. Phenylpropanoid biosynthesis and its regulation. Curr. Opin. Plant Biol. 1: 252-257.

Winke-Shirley, B. 2002. Biosynthesis of flavonoids and effect of stress. Curr. Opin. Plant Biol. 5:218-223.

Wolff, X.Y. and R.R. Coltman. 1990. Productivity of eight leafy vegetable crops crown under shade in Hawaii. J. Amer. Soc. Hort. Sci. 115:182-188. 